\title{
Effects of changes in salinity and osmolality on the rate of uptake of zinc by three crabs of different ecologies
}

\author{
P. S. Rainbow ${ }^{1,2, *}$, W. H. Black ${ }^{2}$ \\ ${ }^{1}$ Department of Zoology, The Natural History Museum, Cromwell Road, London SW7 5BD, United Kingdom \\ ${ }^{2}$ Previously: School of Biological Sciences, Queen Mary and Westfield College, University of London, Mile End Road, \\ London E1 4NS, United Kingdom
}

\begin{abstract}
The effects of salinity and osmolality differences on the uptake rates of dissolved zinc were investigated in 3 crabs of different ecologies - the euryhaline common shore crab Carcinus maenas, the extremely euryhaline Chinese mitten crab Eriocheir sinensis, and a more stenohaline marine crab, the velvet swimming crab Necora puber. Reduced salinities caused increases in the zinc uptake rate of $E$. sinensis as expected from the free metal ion model, with increased free zinc ion availabilities in conditions of reduced chloride complexation. In the cases of C. maenas and N. puber, however, reduced salinity was associated with reduced zinc uptake, a result interpreted in terms of a physiological response by these crabs to low salinity offsetting the physicochemical effect of increased free zinc ion availability. Results can be partly explained by reported changes in apparent water permeability (AWP) made by the crabs to low salinity, although experiments manipulating solution osmotic pressures independently of salinity (and therefore chloride concentrations) indicate that other physiological responses may also be coming into effect. The interaction of physiology and physicochemistry in controlling trace metal uptake from solution clearly varies between species.
\end{abstract}

KEY WORDS: Zinc uptake · Salinity · Osmolality · Crabs · Carcinus maenas · Eriocheir sinensis · Necora puber

\section{INTRODUCTION}

Trace metals are taken up by aquatic invertebrates both from the surrounding medium and from the diet. Metals in solution may be taken up across the cell membrane of permeable surfaces by one or more transport routes (Williams 1981, Simkiss \& Taylor 1989, 1995, Tessier et al. 1994, Rainbow 1997), which include: (1) Carrier-mediated transport, whereby a metal ion binds with a membrane protein and is transported across the membrane. Carrier proteins will have different affinities for different trace metals, thereby providing specificity. (2) A membrane channel, consisting of a protein with a hydrophilic core through which metal

*Email: p.rainbow@nhm.ac.uk ions are transported, in effect an aqueous pore through the lipid membrane, perhaps to be considered as a variant of the carrier protein route (Simkiss 1996, Rainbow 1997). Channels are selective on the basis of the size of the metal ion typically transported: smaller metal ions do not pass because when hydrated they are too large and dehydration is energetically expensive, while larger ions are too large to enter the channel even when dehydrated (Frausto da Silva \& Williams 1991). (3) Passive diffusion of lipid-soluble (non-polar) metal forms which dissolve in the lipid bilayer. Such forms would include alkyl-metal compounds and neutral inorganically complexed metal species (e.g. $\mathrm{ZnCl}_{2}{ }^{0}$ ). (4) Endocytosis, when a region of the cell membrane invaginates to engulf a metaliferous particle (e.g. particulate iron hydroxide) for transfer into an intracellular vesicle. 
It is generally considered that it is the free metal ion that is the form of the metal that is available for transport across the cell membrane via a carrier protein or through a membrane channel, and therefore that the free metal ion is the most bioavailable form of dissolved metal (Tessier et al. 1994, Campbell 1995). The affinity of trace metals for sulphur and nitrogen ensures that they have a high affinity for proteins (Nieboer \& Richardson 1980, Williams 1981). Once trace metals are across the cell membrane, their binding within the cell with large non-diffusible cytosolic proteins of higher affinity for the metal ensures that they continue to enter passively, even though the internal concentration of total metal in the cell is higher than the external dissolved metal concentration (Williams 1981). In short, any free metal ion within the cell is soon bound and there is a concentration gradient across the membrane into the cell, even if the external dissolved free metal ion concentration appears very low. In seawater, dissolved zinc, like many other trace metal ions, is partitioned in equilibria between (predominantly) inorganic and organic complexing agents (Bruland 1983, Turner 1995). Thus zinc is complexed by chloride and hydroxide with about $47 \%$ present as the free hydrated $\mathrm{Zn}^{2+}$ ion (Mantoura et al. 1978, Bruland 1983, Rainbow et al. 1993).

While the concentration gradient for trace metal entry is maintained passively by their high affinity binding intracellularly, concentration gradients for other metal ions may require the use of energy, for example in membrane-bound ATPases (Rainbow 1997). Major ions like $\mathrm{Na}^{+}$and $\mathrm{Ca}^{2+}$ do not have such high affinities for complexing agents including proteins (Nieboer \& Richardson 1980), and remain uncomplexed as hydrated free metal ions in seawater (Bruland 1983). Thus $\mathrm{Na}^{+} \mathrm{K}^{+} \mathrm{ATPase}$ in the basal cell membrane of the ionocyte cells of the gills of decapod crustaceans maintains a low intracellular $\mathrm{Na}^{+}$concentration, allowing sodium to enter apically down a concentration gradient via sodium channels (Rainbow 1997). Similarly an ionic concentration gradient promoting $\mathrm{Ca}^{2+}$ uptake via apical $\mathrm{Ca}$ channels is maintained by the active pumping out of $\mathrm{Ca}^{2+}$ ions, perhaps via a basal $\mathrm{Ca}^{2+}$ ATPase in the same gill ionocytes of decapods (Rainbow 1997). It is relevant that these cells play a key role in osmoregulation in decapod crustaceans in reduced salinities (see below).

It should not be assumed that the uptake of the dissolved metal ion will take place by only one route. Thus uptake of zinc will take place via the diffusion of $\mathrm{ZnCl}_{2}{ }^{0}$ through the lipid bilayer of the cell membrane as well as via the binding of the free $\mathrm{Zn}^{2+}$ ion to a membrane protein, but there may be an enormous difference between rates of entry by different routes. Similarly it is inevitable that trace metal ions will enter via channels for major ions if they are of the same size, but again the relative importance of this route will vary, not least with the activity of the pumps promoting major ion uptake. For example the cadmium ion $\mathrm{Cd}^{2+}$ has an ionic radius of $0.92 \AA$ while that of $\mathrm{Ca}^{2+}$ is $0.94 \AA$ (Williams \& Frausto da Silva 1996), ensuring some entry of Cd by Ca channels (Rainbow 1997).

Evidence is accumulating on the factors that affect the uptake of dissolved trace metals, including zinc, by crustaceans, throwing light thereby on the significant route(s) of metal uptake (Rainbow 1995, 1997). The free zinc ion does appear to play a central role. The free metal ion concentration will alter with changes in total metal concentration (remaining at $47 \%$ of total dissolved zinc concentration in seawater), increasing or decreasing the rate of metal uptake by the crustacean. The free metal ion concentration can, however, also be altered without changing the total dissolved metal concentration, by altering the availability of water-soluble metal binding ligands. Thus, the addition of the chelating agent EDTA reduces the absolute equilibrium concentration of the free $\mathrm{Zn}^{2+}$ ion, and reduces the rate of zinc uptake by the amphipod Orchestia gammarellus (Rainbow et al. 1993) and the decapod Palaemon elegans (Nugegoda \& Rainbow 1988), in the latter case in direct correlation with the predicted free zinc ion concentration (O'Brien et al. 1990).

Changes in salinity will also alter the concentration of inorganic complexing agents, particularly that of chloride. Thus the concentration of free zinc ions will increase in a predictable way as salinity decreases (Rainbow et al. 1993), with no change in total dissolved zinc concentration. If the rate of uptake is, therefore, determined by the free zinc ion concentration, decreases in salinity should produce predictable increases in zinc uptake rate. This is indeed the case for the decapod crustaceans Palaemon elegans and Palaemonetes varians (Nugegoda \& Rainbow 1989a,b), and for the amphipod Orchestia gammarellus at salinities down to 25 (Rainbow et al. 1993, Rainbow \& Kwan 1995).

Changes in salinity do not only cause physicochemical changes in zinc speciation in the medium. They may also have an effect on the physiology of an aquatic invertebrate. An estuarine decapod crustacean exposed to reduced salinity will have body fluids hypertonic to the medium, promoting the osmotic uptake of water. A decapod typically responds to the increased osmotic uptake of water by increasing urine production; the urine is isotonic to the blood and its increased production results in the loss of major ions as well as the increased expulsion of water (Mantel \& Farmer 1983). The loss of major ion is balanced by active uptake of major ions in the gill ionocytes. Thus a decrease in salinity will be associated with a physiological response increasing the active uptake of major 
ions like sodium. If a trace metal enters via the route for uptake of a major ion, then decreased salinity will cause increased trace metal ion uptake by this route, irrespective of any physicochemical change promoting release of the trace metal ion from inorganic complexation.

One way to distinguish between the physicochemical effect of decreased salinity promoting free metal ion activity and a physiological response on the part of the decapod to low salinity (strictly low osmolality) is to vary salinity and osmolality independently. The salinity of a solution is a measure of the concentration of inorganic ionic solutes, while the osmolality of a medium is dependent on the total solutes present (inorganic or organic). In seawater, inorganic ions, dominated by sodium and chloride ions, in effect control osmolality, and changes in salinity and osmolality occur concurrently as seawater is diluted in estuaries, with consequent effects on the osmotic balance of aquatic organisms. It is possible, however, to separate changes in osmolality from those in salinity, as achieved by Nugegoda \& Rainbow (1989b) by the addition of an organic molecule, in this case the sugar D-fructose, which does not chelate zinc. Working on Palaemon elegans, Nugegoda \& Rainbow (1989b) increased the osmolality of $25 \%$ seawater to that of $75 \%$ seawater, without increasing the concentration of inorganic ions present. This adjusted medium would show the zinc complexation characteristics (and hence the free zinc ion concentration) of $25 \%$ seawater, but stimulate energy-dependent major ion uptake by the decapod to the same extent as $75 \%$ seawater. In the event, the zinc uptake rate of $P$. elegans matched that in $25 \%$ seawater, not $75 \%$ seawater (Nugegoda \& Rainbow 1989b). The uptake of zinc by this decapod therefore appears to involve a route independent of active uptake routes for major ions.

A physiological parameter that differs between crustaceans with the potential to affect trace metal uptake rates is the integumental permeability (Rainbow 1997, 1998). Integumental permeabilities (measured as Apparent Water Permeability, AWP) of crustaceans decrease along the habitat salinity gradient from marine via estuarine to freshwaters (Rudy 1967, Bolt 1983, Mantel \& Farmer 1983, Rasmussen \& Andersen 1996, Rainbow \& Black 2001), and crustacean metal uptake rates do similarly decrease along this habitat gradient (Rainbow 1997, 1998). Some crustaceans have the ability to alter integumental permeability as a physiological response to salinity change (Rasmussen \& Andersen 1996, Rainbow \& Black 2001) and this response may correspondingly affect trace metal uptake rates (Rainbow 1997). These crustaceans include the crab Carcinus maenas (Smith 1970, Rasmussen \& Bjerregaard 1995, Rasmussen \& Andersen
1996), the caridean decapods Crangon crangon, Palaemon longirostris and Palaemonetes varians (Campbell \& Jones 1990) and the amphipod Gammarus duebeni (Bolt 1983).

Chan et al. (1992) interpreted some apparently anomalous results of the effect of reduced salinities on zinc (and cadmium) uptake rates in the shore crab Carcinus maenas in terms of apparent water permeabilities. Chan et al. (1992) compared the zinc and cadmium uptake rates of 2 populations of shore crabsone from the Firth of Clyde, Scotland, living at high salinity (33), and the other from the lower salinity (15 to 20) environment of the southern Kattegat, Denmark. Zinc uptake rates of the crabs of these 2 populations did not show the increases with decreased salinity expected from the physicochemically determined increases in free zinc ion concentrations. The Scottish crabs actually showed a decrease in zinc uptake rate with a salinity decrease from 35 to 15, while the Danish crabs showed no change in zinc uptake rates between 33 and 15 ; in all cases the Danish crabs had the lower zinc uptake rates (Chan et al. 1992). The authors proposed the hypothesis that the results may be explained in terms of changes in AWP, a physiological response to low salinity counteracting the physicochemically driven increases in free zinc ion availability. Chan et al. (1992) hypothesised that the AWP of the Scottish crabs would decrease with reduced salinity, in line with the results of Smith (1970) then available in the literature (later to be extended by Rasmussen \& Bjerregaard (1995) and Rasmussen \& Andersen (1996)). By contrast, the Danish crabs with a lifetime history of exposure to low salinity would be expected to already exhibit a low AWP, causing a low zinc uptake rate and with smaller subsequent changes in AWP matching the physicochemical effects serving to increase the zinc uptake rate with salinity reduction (Chan et al. 1992, Rainbow 1995).

It was stated earlier that the zinc uptake rate of the amphipod crustacean Orchestia gammarellus increased with reduction in salinity down to 25 as predicted by changes in the free metal ion availability (Rainbow et al. 1993). What was also found, however, was that at the lower salinity of 15 , the uptake rate of zinc was equal to that at 25 with no further increase as expected from changes in free metal ion concentrations (Rainbow et al. 1993, Rainbow \& Kwan 1995). (The results could not be interpreted in terms of the saturation of any [enzyme-mediated?] uptake process - the uptake rates were well below those measured at higher dissolved exposure concentrations of zinc and cadmium.) Thus the amphipod had made a physiological response to the low salinity that had counteracted the physicochemical effect of salinity on zinc speciation. Follow up work (Rainbow \& Kwan 1995), however, ruled out 
changes in AWP as being the probable physiological response involved in the case of this crustacean.

Thus the uptake of dissolved zinc by crustaceans is clearly affected by the availability of the free zinc ion, an availability that is controlled by physicochemical features of the surrounding medium (Rainbow 1995, 1997). Some crustaceans, however, do under certain circumstances appear to have the capacity to make physiological responses to salinity change that have a subsequent effect on the zinc uptake rate. The major aim of this paper, therefore, is to investigate the interaction of physicochemical effects of low salinity on the uptake of zinc by crustaceans, and any physiological response to low salinity made by the crustacean. To this end, we chose a suite of 3 crabs from habitats of different salinity exposure: (1) Carcinus maenas, the common shore crab, a littoral and sublittoral euryhaline species, occurring in tide pools, estuaries, salt marshes and shallow sublittoral waters to $60 \mathrm{~m}$ depth (Ingle 1980). This crab is known to make physiological responses to salinity changes which can serve to offset changes in zinc speciation caused by such changes (see above). (2) Eriocheir sinensis, the Chinese mitten crab, an introduced alien in Britain, which spends its adult life in freshwater, migrating to river estuaries to breed (Clark et al. 1998). These crabs are extremely euryhaline, tolerating the full range of salinities from freshwater to marine. (3) Necora puber, the velvet swimming crab, a presumed more stenohaline marine species, occurring from the lower shore down to $80 \mathrm{~m}$ on rocky substrata (Ingle 1980).

We compare zinc uptake rates in these 3 crabs under different salinities and osmolalities, and attempt to interpret the interspecific differences found in terms of the interaction of physicochemistry and physiology in these crabs of different ecologies. As part of this comparative study, we measured changes in the apparent water permeabilities of the 3 crabs under different salinity conditions (Rainbow \& Black 2001), and will use these results in our interpretation.

\section{MATERIALS AND METHODS}

Adult male Carcinus maenas (wet weights 60 to $80 \mathrm{~g}$ ) and Necora depurator (wet weights 20 to $45 \mathrm{~g}$ ) were obtained from the University Marine Biological Station, Millport, Isle of Cumbrae, Scotland, after collection locally. Adult male and female Eriocheir sinensis (wet weights 70 to $110 \mathrm{~g}$ ) were collected from the filter screens of Lots Road power station, Chelsea, on the estuary of the River Thames in west London. Although the moult stage was not determined specifically for each crab, any crab showing any apparent sign of not being in intermoult was discarded. All crabs were therefore assumed to be in intermoult. C. maenas and $N$. puber were transferred on collection to aquaria and maintained in natural seawater at a salinity of 33 whilst E. sinensis were maintained in artificial seawater (Tropic Marin Neu [TMN], Tropicarium Buchslag) at 15. All crabs were kept at $10^{\circ} \mathrm{C}$ under a $12 \mathrm{~h}$ light: $12 \mathrm{~h}$ dark cycle and fed with lambs' heart 3 times a week.

For acclimation and for all experiments, crabs were maintained in artificial seawater (TMN). The choice of a reproducible medium is crucial to these experiments. The physicochemistry of the seawater medium has a very significant effect on the uptake of trace metals such as zinc by crustaceans (Rainbow 1995, 1997). It is impossible to ensure reproducibility of dissolved inorganic and (more particularly) organic contents of stored or recently collected field seawater batches, with consequent variable and uncontrollable effects on zinc chelation and subsequent rates of zinc uptake by crustaceans. Crabs were acclimated in TMN of a chosen salinity and osmolality for $7 \mathrm{~d}$ (see Henry \& Cameron 1982, Mantel \& Farmer 1983) before experimental exposure to zinc. The sodium concentration of the blood of each crab was measured daily in order to follow and confirm the process of acclimation (Mantel \& Farmer 1983), but those data are not presented here. During acclimation, crabs were maintained individually in partitioned, perforated Perspex boxes in $10 \mathrm{l}$ tanks of aerated TMN at $10^{\circ} \mathrm{C}$, under a $12 \mathrm{~h}$ light: $12 \mathrm{~h}$ dark cycle. Crabs were not fed during acclimation or exposure periods.

After $7 \mathrm{~d}$ acclimation, crabs were transferred into individual Perspex exposure tanks containing $1 \mathrm{l}$ of exposure medium (TMN) of the required salinity and

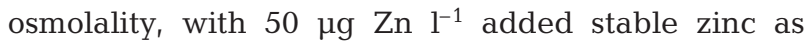
$\mathrm{ZnCl}_{2}$, at $10^{\circ} \mathrm{C}$ for $4 \mathrm{~d}$. Each medium was labelled with radioactive $\mathrm{Zn}^{65}$ (Dupont Nen Products) at a concentration of $5 \mu \mathrm{Ci} \mathrm{l}^{-1}$, with no significant effect on the total dissolved zinc concentration present.

Blood samples $(0.1 \mathrm{ml})$ were taken from crabs by puncture of the arthrodial membranes of leg joints using a $1 \mathrm{ml}$ syringe with a $0.5 \mathrm{~mm}$ gauge needle (Monoject, Sherwood Medical). Each blood sample was transferred into an acid washed glass vial. The samples were counted for labelled zinc on an LKB 1282 Compugamma Universal Gamma Counter. After gamma counting, each $0.1 \mathrm{ml}$ blood sample was acid digested with $0.1 \mathrm{ml}$ concentrated nitric acid (Aristar grade, BDH Ltd) at $100^{\circ} \mathrm{C}$ for $2 \mathrm{~d}$, diluted to $2 \mathrm{ml}$ with double distilled water, and analysed for total zinc concentration by atomic absorption spectrophotometry on an IL-175 spectrophotometer (Instrumentation Laboratory). The total sodium concentrations of the blood digests were analysed using a Corning 400 flame photometer, calibrated against a series of standards prepared from a $1000 \mathrm{\mu g} \mathrm{ml}^{-1}$ stock (BDH Ltd) (data not presented). 
The kinetics of the uptake and accumulation of radioactively labelled zinc in the blood of crabs like Carcinus maenas are well known (Martin \& Rainbow $1998 \mathrm{a}, \mathrm{b})$, and the use of parameters of these accumulation kinetics in the blood are well-established proxy measures of the rate of uptake of dissolved zinc by the crab (Rainbow et al. 1999, 2000). The labelled Zn concentration in the haemolymph continues to increase over the exposure period. The rate of this increase (the regression coefficient of the best-fit line, $\mathrm{ng} \mathrm{ml}^{-1} \mathrm{~d}^{-1}$ ) is directly proportional to the concentration of available $\mathrm{Zn}$ in the exposure solution, and is a relative measure of the crab's uptake rate of dissolved metal (Martin \& Rainbow 1998a, Rainbow et al. 1999, 2000).

Effects of salinity changes. Carcinus maenas: Six groups of 7 crabs were exposed individually in 11 TMN under the following acclimated $(\mathrm{A}, \mathrm{B}, \mathrm{C})$ and non-acclimated (D, E, F) salinity conditions: Group A: At 33 during $7 \mathrm{~d}$ pre-exposure and $4 \mathrm{~d}$ exposure. Group B: At 20 during $7 \mathrm{~d}$ pre-exposure and $4 \mathrm{~d}$ exposure. Group C: At 15 during $7 \mathrm{~d}$ pre-exposure and $4 \mathrm{~d}$ exposure. Group D: At 33 for 7 d pre-exposure and at 20 for $4 \mathrm{~d}$ exposure. Group E: At 33 for 7 d pre-exposure and at 15 for $4 \mathrm{~d}$ exposure. Group F: At 20 for 7 d pre-exposure and at 33 for 4 d exposure.

Eriocheir sinensis: Seven groups of 8 crabs were exposed individually in $11 \mathrm{TMN}$ under the following acclimated (A, B, C, D) and non-acclimated (E, F, G) salinity conditions: Group A: At 33 for 7 d pre-exposure and $4 \mathrm{~d}$ exposure. Group B: At 20 for $7 \mathrm{~d}$ pre-exposure and $4 \mathrm{~d}$ exposure. Group C: At 15 for $7 \mathrm{~d}$ pre-exposure and $4 \mathrm{~d}$ exposure. Group D: At 5 during $7 \mathrm{~d}$ pre-exposure and $4 \mathrm{~d}$ exposure. Group E: At 15 for $7 \mathrm{~d}$ pre-exposure and at 33 for $4 \mathrm{~d}$ exposure. Group F: At 15 for $7 \mathrm{~d}$ pre-exposure and at 20 for $4 \mathrm{~d}$ exposure. Group G: At 15 for $7 \mathrm{~d}$ pre-exposure and at 5 for $4 \mathrm{~d}$ exposure.

Necora puber: Two groups of 8 crabs were exposed individually in $1 \mathrm{l}$ TMN under the following salinity conditions: Group A: At 33 for 7 d pre-exposure and at 33 for $4 \mathrm{~d}$ exposure. Group B: At 33 for $7 \mathrm{~d}$ preexposure and at 25 for $4 \mathrm{~d}$ exposure. Because of the less euryhaline nature of Necora puber, crabs were maintained in 33 and not acclimated to the lower salinities for the $7 \mathrm{~d}$ pre-exposure to labelled zinc.

On Day 7 of each experiment, all groups of crabs were exposed to $50 \mu \mathrm{g} \mathrm{l}^{-1}$ zinc labelled with $5 \mu \mathrm{Ci} \mathrm{l}^{-1}$ $\mathrm{Zn}^{65}$ as a tracer. $0.1 \mathrm{ml}$ haemolymph samples were taken from each crab on most day pre- and during exposure, and measured for labelled zinc, total zinc and total sodium concentrations.

Effects of osmolality changes. The salinity of a solution is a measure of the concentration of inorganic ionic solutes (theoretically defined as the total number of grams of dissolved salt ions present in $1 \mathrm{~kg}$ of seawater, now expressed as a scale without dimensions), while the osmolality of a medium is dependent on the total dissolved particles present (inorganic or organic). A 1 molal solution (containing 1 mole of solute in $1 \mathrm{~kg}$ of solvent) has an osmolality of 1 osmole per kilogram $\left(O s m \mathrm{~kg}^{-1}\right)$. In seawater, inorganic ions, dominated by sodium and chloride ions, in effect control osmolality and changes in salinity and osmolality occur concurrently as seawater is diluted in estuaries. It is possible, however, for the purpose of these experiments to separate changes in osmolality from those in salinity by the addition of the sugar D-fructose which does not chelate zinc (Nugegoda \& Rainbow 1989b). No evidence of any detrimental effect of fructose on the experimental crustaceans was apparent, either in this study or in that of Nugegoda \& Rainbow (1989b).

The osmolality of each of a diluted series of TMN was determined by the freezing point depression method on an Osmette $\mathrm{S}$ osmometer (Precision Systems). The osmolalities of TMN with salinities of 33, 20, 15, 10 and 5 were 853, 606, 432, 261 and 137 mOsm $\mathrm{kg}^{-1}$ respectively. Where required, the osmolality of the solution was raised by addition of the appropriate amount of D-fructose to the TMN. For example, the osmolality of TMN with a salinity of 15 was raised by $421 \mathrm{mOsm} \mathrm{kg} \mathrm{kg}^{-1}$ through the addition of $6.78 \mathrm{~g} \mathrm{D}$-fructose per $100 \mathrm{~g}$ of TMN solution, to give a solution with a salinity of 15 with an osmolality of $853 \mathrm{mOsm} \mathrm{kg} \mathrm{kg}^{-1}$ (i.e. osmolality equivalent to TMN with a salinity of 33).

Carcinus maenas: Five groups of 7 crabs were exposed individually in $11 \mathrm{TMN}$ of the following salinities and osmolalities: Group A: At 33 (853 $\mathrm{mOsm} \mathrm{kg}^{-1}$ ) during $7 \mathrm{~d}$ pre-exposure and $4 \mathrm{~d}$ exposure. Group B: At 20 (606 mOsm kg-1) during $7 \mathrm{~d}$ pre-exposure and $4 \mathrm{~d}$ exposure. Group C: At 15 (432 $\mathrm{mOsm} \mathrm{kg}^{-1}$ ) during $7 \mathrm{~d}$ pre-exposure and $4 \mathrm{~d}$ exposure. Group D: At 20 (853 mOsm $\mathrm{kg}^{-1}$ ) during $7 \mathrm{~d}$ pre-exposure and $4 \mathrm{~d}$ exposure. Group E: At 15 (853 $\mathrm{mOsm} \mathrm{kg}^{-1}$ ) during $7 \mathrm{~d}$ pre-exposure and $4 \mathrm{~d}$ exposure.

Eriocheir sinensis: Five groups of 5 crabs were exposed individually in $11 \mathrm{TMN}$ of the following salinities and osmolalities: Group A: At 15 (432 $\left.\mathrm{mOsm} \mathrm{kg}^{-1}\right)$ during $7 \mathrm{~d}$ pre-exposure and $4 \mathrm{~d}$ exposure. Group B: At 10 (261 mOsm kg-1) during $7 \mathrm{~d}$ pre-exposure and $4 \mathrm{~d}$ exposure. Group C: At 5 (137 mOsm kg-1) during 7 d preexposure and $4 \mathrm{~d}$ exposure. Group D: At 10 (432 mOsm $\mathrm{kg}^{-1}$ ) during $7 \mathrm{~d}$ pre-exposure and $4 \mathrm{~d}$ exposure.

Group E: At 5 (432 mOsm $\left.\mathrm{kg}^{-1}\right)$ during $7 \mathrm{~d}$ preexposure and $4 \mathrm{~d}$ exposure.

Necora puber: Three groups of 7 crabs were exposed individually in $11 \mathrm{TMN}$ of the following salinities and osmolalities: Group A: At 33 (853 mOsm kg ${ }^{-1}$ ) during $7 \mathrm{~d}$ pre-exposure and $4 \mathrm{~d}$ exposure. Group B: At 33 (853 $\mathrm{mOsm} \mathrm{kg}^{-1}$ ) during $7 \mathrm{~d}$ pre-exposure and at 25 (651 $\mathrm{mOsm} \mathrm{kg}^{-1}$ ) for $4 \mathrm{~d}$ during exposure. Group C: At 


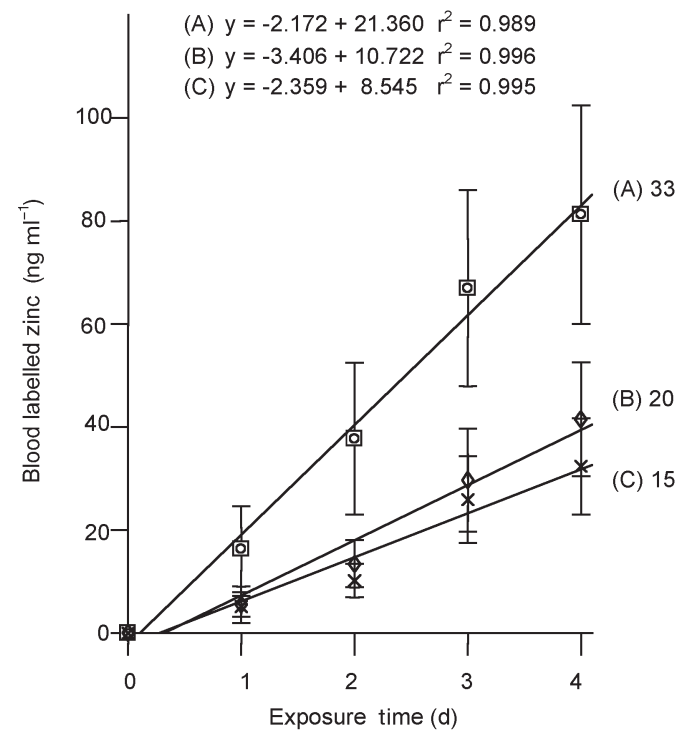

Fig. 1. Carcinus maenas. Uptake of labelled zinc into the blood under acclimated conditions. Crabs were exposed for $4 \mathrm{~d}$ to $50 \mu \mathrm{g} \mathrm{l}^{-1}$ labelled $\mathrm{Zn}$ at 3 salinities (A) 33, (B) 20, and (C) 15 (mean $\pm 1 \mathrm{SD}, \mathrm{n}=7$ ) after $7 \mathrm{~d}$ pre-exposure at the same salinity

33 (853 $\mathrm{mOsm} \mathrm{kg}^{-1}$ ) during $7 \mathrm{~d}$ pre-exposure and at 25 (853 mOsm kg-1) for $4 \mathrm{~d}$ during exposure.

On Day 7 of each experiment, all groups of crabs were exposed to $50 \mu \mathrm{g} \mathrm{l}^{-1}$ zinc labelled with $5 \mu \mathrm{Ci} \mathrm{l}^{-1}$ $\mathrm{Zn}^{65}$ as a tracer. $0.1 \mathrm{ml}$ haemolymph samples were taken from each crab on each day during exposure and measured for labelled zinc.

Statistical analysis. Statistical analyses were carried out according to Rees (1987) and Sokal \& Rohlf (1969). The null hypothesis $\left(H_{0}\right)$ tested was that there was no association or difference between variables under test, and rejection of the null hypothesis was at the $5 \%$ probability level $(p<0.05)$. Samples of each data set were normally distributed (checked for homoscedas- ticity), and the parametric tests ANOVA and ANCOVA were used to compare means and functional relationships described by regression equations respectively.

\section{RESULTS}

\section{Effects of salinity changes}

\section{Carcinus maenas}

Fig. 1 shows that, under acclimated regimes, the uptake of labelled zinc into the blood of Carcinus maenas decreased with a decrease in salinity of the exposure medium. The rate of labelled zinc uptake is significantly lower at salinities of 20 (Group B) and 15 (Group C) than at 33 (ANCOVA of slopes (uptake rates): A \& B FS $=31.8, \mathrm{df}=2,68, \mathrm{p}<0.01 ; \mathrm{A} \& \mathrm{C} F S=$ 42.4 , df $=2,68, p<0.01$ ). There was no significant difference in the mean rate of zinc uptake into the haemolymph when Groups B and C were compared i.e. at salinities of 20 and 15 (ANCOVA: B \& C FS = 2.30, $\mathrm{df}=2,68, \mathrm{p}=0.13$ ).

The effect of transfer of crabs from a high salinity of 33 in which they had been maintained for $7 \mathrm{~d}$ into a lower salinity during zinc exposure (i.e. non-acclimated regimes), on the rates of labelled zinc uptake into the blood was also studied. Fig. 2 compares the slopes of the regression lines (uptake rates) of Group A (33 to 33) and the non-acclimated crabs of Groups D (33 to 20) and $E$ (33 to 15). The rates of zinc uptake into the blood were significantly reduced on exposure of crabs to lower salinities under non-acclimated regimes (ANCOVA of slopes: A and D FS $=12.3$, df $=2,68, \mathrm{p}<$ 0.01 ; A and $E F_{S}=14.5, \mathrm{df}=2,68, \mathrm{p}<0.01$ ), as for acclimated crabs. Short-term transfer for $4 \mathrm{~d}$ from high to low salinity does affect (reduce) the rate of labelled zinc entering the blood of Carcinus maenas at both 20 and 15 , but the reduction is not so great as in the case
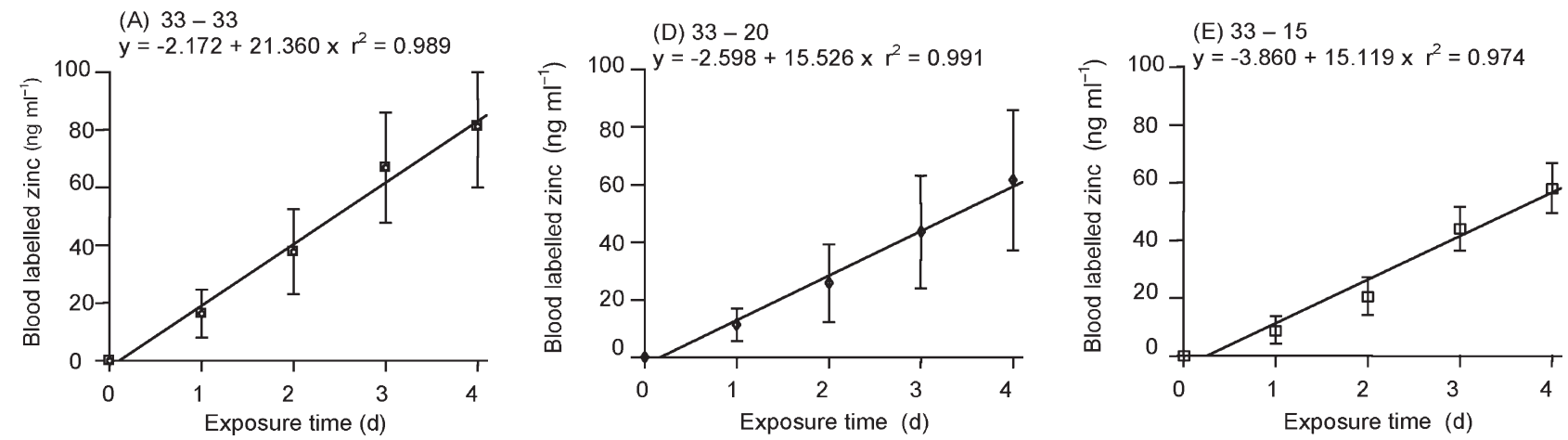

Fig. 2. Carcinus maenas. Uptake of labelled zinc into the blood under non-acclimated conditions. Crabs were exposed for $4 \mathrm{~d}$ to $50 \mu \mathrm{g} \mathrm{l}^{-1}$ labelled $\mathrm{Zn}$ at salinities (A) 33, (D) 20, and (E) 15 (mean $\pm 1 \mathrm{SD}, \mathrm{n}=7$ ) after 7 d pre-exposure at 33 
of crabs acclimated for $7 \mathrm{~d}$ to each lower salinity before experimental exposure to zinc.

Fig. 3 shows that the rate of labelled zinc entering the blood was unaffected by short-term transfer of crabs from a salinity of 20 to a higher exposure salinity of 33 (Group F) when compared with Group B acclimated at 20 (ANCOVA of slopes (uptake rates): $\mathrm{B}$ and $\mathrm{F} F \mathrm{~F}=0.00$ $\mathrm{df}=2,68, \mathrm{p}=0.98)$. Thus short-term transfer for $4 \mathrm{~d}$ from low to high salinity does not affect the rate of labelled zinc influx into the blood of Carcinus maenas.

There was no significant difference (ANOVA, data not shown) in the total blood zinc concentrations between groups of crabs exposed at a salinity of 33 and those exposed to lower salinities under acclimated or non-acclimated conditions. The total haemolymph concentrations of zinc ranged from 15 to $38 \mu \mathrm{g} \mathrm{ml}^{-1}$ with a grand mean $( \pm 1 \mathrm{SD})$ of $26.5 \pm 5.22 \mu \mathrm{g} \mathrm{Zn} \mathrm{m} \mathrm{l}^{-1}(\mathrm{n}=168)$. At the highest measured uptake rate of labelled zinc into the blood (21.36 $\mathrm{ng} \mathrm{ml}^{-1} \mathrm{~d}^{-1}$ at $33(\mathrm{~A})$ ), the new zinc added to the blood would be only $0.085 \mu \mathrm{g} \mathrm{ml}^{-1}$, an addition which would not be detectable when measuring total zinc concentrations. The lack of significant change in zinc concentration in the blood resulting from the addition of new zinc is therefore not unexpected. More to the point, salinity change did not cause any physiological response affecting the concentration of total zinc in the haemolymph over the $11 \mathrm{~d}$ period of experimentation, that might otherwise compromise the use of this technique to measure zinc uptake into the blood.

\section{Eriocheir sinensis}

Fig. 4 shows the uptake rates of labelled zinc into the blood of acclimated crabs in Groups A (33), B (20), C (15) and D (5). In contrast to the situation for Carcinus maenas, the uptake rates of zinc into the blood increased significantly with a decrease in salinity (ANCOVA of slopes: A and B $F_{S}=80.5$, df $=2,78$, $\mathrm{p}<0.01 ; \mathrm{A}$ and $\mathrm{C} F S=124, \mathrm{df}=2,78, \mathrm{p}<0.01 ; \mathrm{A}$ and D $F_{S}=43.9, \mathrm{df}=2,78, \mathrm{p}<0.01 ; \mathrm{B}$ and $\mathrm{C} F S=23.6, \mathrm{df}=$ $2,78, \mathrm{p}<0.01 ; \mathrm{B}$ and D FS $=27.2, \mathrm{df}=2,78, \mathrm{p}<0.01$; $\mathrm{C}$ and $\mathrm{D} F S=19.5, \mathrm{df}=2,78, \mathrm{p}<0.01$ ).

Crabs in Groups E, F and G were exposed to labelled zinc at a different salinity than their pre-exposure acclimation salinity of 15 . Fig. 5 shows the mean uptake rates of labelled zinc into the blood of Eriocheir sinensis under treatments C (15 to 15$), \mathrm{E}$ (15 to 33), F (15 to 20 ) and $G$ (15 to 5). As for acclimated crabs, generally the uptake rates of labelled zinc increased significantly with a decrease in exposure salinity (ANCOVA of slopes (uptake rates): $\mathrm{C}$ and $\mathrm{E} F S=76.7$, $\mathrm{df}=2,78, \mathrm{p}<0.01 ; \mathrm{C}$ and $\mathrm{F} F S=74.8, \mathrm{df}=2,78, \mathrm{p}<0.01$; $\mathrm{C}$ and $\mathrm{G} F \mathrm{~F}=7.31, \mathrm{df}=2,78, \mathrm{p}<0.01)$. However, crabs transferred from a salinity of 15 into 33 (Group E) and 20 (Group F) had zinc uptake rates not significantly different from each other, although these rates were

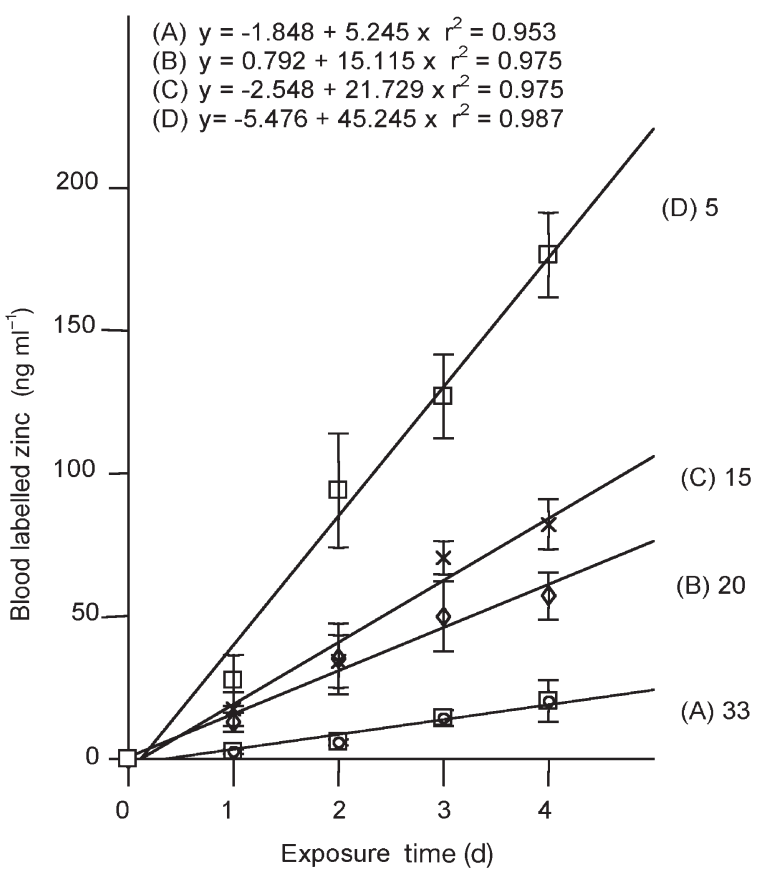

Fig. 4. Eriocheir sinensis. Uptake of labelled zinc into the blood under acclimated conditions. Crabs were exposed for $4 \mathrm{~d}$ to $50 \mu \mathrm{g} \mathrm{l}^{-1}$ labelled $\mathrm{Zn}$ at salinities of (A) 33, (B) 20, (C) 15 and (D) 5 (mean $\pm 1 \mathrm{SD}, \mathrm{n}=8$ ) after $7 \mathrm{~d}$ pre-exposure at the same salinity 


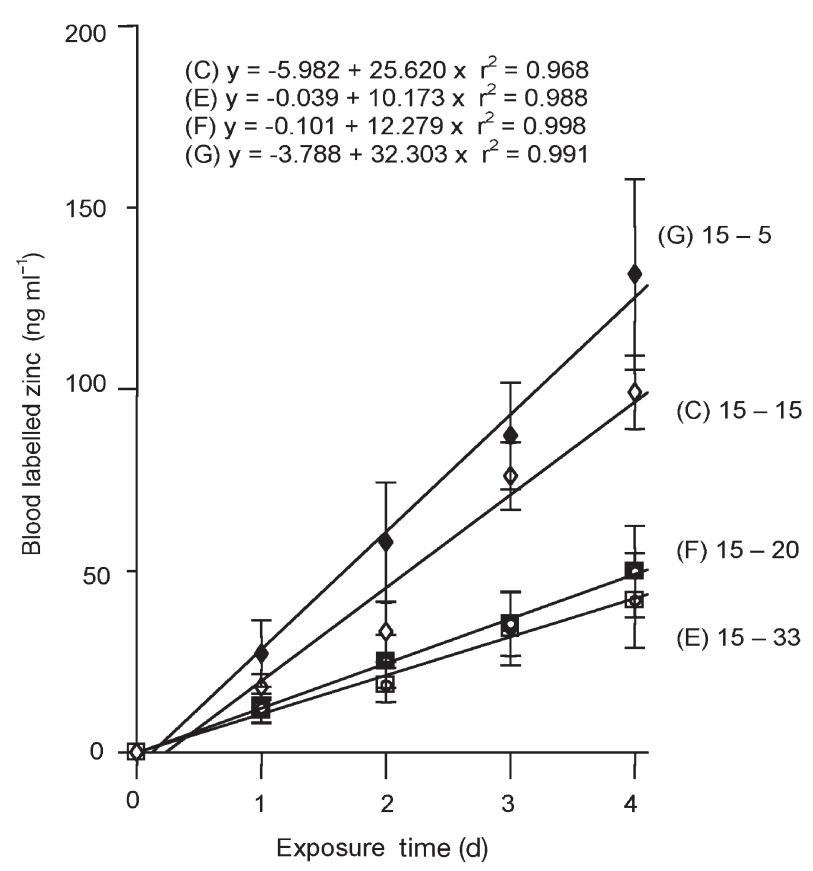

Fig. 5. Eriocheir sinensis. Uptake of labelled zinc into the blood under non-acclimated conditions. Crabs were exposed for $4 \mathrm{~d}$ to $50 \mu \mathrm{g} \mathrm{l}^{-1}$ labelled $\mathrm{Zn}$ at salinities of (C) 15, (E) 33, (F) 20 and $(\mathrm{G}) 5$ (mean $\pm 1 \mathrm{SD}, \mathrm{n}=8$ ) after $7 \mathrm{~d}$ pre-exposure at 15

significantly lower than those of crabs transferred into 5 (Group G) (ANCOVA: $E$ and $F F S=0.08, d f=2,78$, $\mathrm{p}=0.78 ; \mathrm{E}$ and $\mathrm{G} F S=108, \mathrm{df}=2,78, \mathrm{p}<0.01 ; \mathrm{F}$ and $\mathrm{G}$ $\left.F_{S}=106, \mathrm{df}=2,78, \mathrm{p}<0.01\right)$. Results for exposure $\mathrm{C}$ in each of Figs. 4 and 5 are not identical because the experiments could not be run exactly at the same time for logistical reasons, but they are consistent.

None of the salinity treatments caused any significant differences in the total blood zinc concentrations of the crabs. The total blood concentrations of zinc ranged from 7 to $14 \mu \mathrm{g} \mathrm{ml}^{-1}$ in Eriocheir sinensis with a grand mean $( \pm 1 \mathrm{SD})$ of $9.44 \pm 1.99 \mu \mathrm{g} \mathrm{Zn} \mathrm{ml}^{-1}(\mathrm{n}=280)$. Thus, as for Carcinus maenas, salinity change did not affect the concentration of total zinc in the haemolymph.

\section{Necora puber}

Fig. 6 depicts the uptake of labelled zinc into the blood of Necora puber at 33 to 33 and 33 to 25. Comparison of the uptake rates from Group A (33 to 33) and Group B (33 to 25) showed that the uptake of labelled zinc was significantly reduced on short term transfer to a lower salinity (ANCOVA of slopes [uptake rates]: $F_{S}$ $=4.67, \mathrm{df}=2,78, \mathrm{p}<0.05)$. Thus the crabs responded rapidly to the transfer from TMN at a salinity of 33 to a salinity of 25 .
Total zinc concentrations in the blood of Necora puber (grand mean [ $\pm 1 \mathrm{SD}] 8.74 \pm 1.47 \mu \mathrm{g} \mathrm{Zn} \mathrm{m}{ }^{-1}, \mathrm{n}=$ 80) showed no significant changes in the experiment.

\section{Effects of osmolality changes}

This series of experiments attempted to separate possible effects of changes in the osmotic pressure of the medium on the physiology of the crabs, from the physicochemical effects of changes in salinity (particularly chloride concentration) on zinc uptake by the crabs.

\section{Carcinus maenas}

Fig. 7 shows the already observed (Fig. 1) decrease in the rate of zinc uptake by Carcinus maenas at a salinity of 20 from that at 33, when the media have the osmolalities appropriate to each salinity (606 and $853 \mathrm{mOsm} \mathrm{kg}^{-1}$ respectively). Fig. 7 also shows that the same reduction in salinity from 33 to 20, but now with no change in osmolality from $853 \mathrm{mOsm} \mathrm{kg}{ }^{-1}$, also produces a reduction in zinc uptake rate but a smaller reduction than previously. Thus the rates of zinc uptake into the blood of crabs in Groups B and D (Fig. 7) were significantly lower (ANCOVA: A and B $F_{S}=11.9, \mathrm{df}=2,68, \mathrm{p}<0.01 ; \mathrm{A}$ and $\mathrm{D} F S=7.62, \mathrm{df}=$ $2,68, \mathrm{p}<0.01)$ than the rate in crabs in Group A. There was also a significant difference between rates of zinc

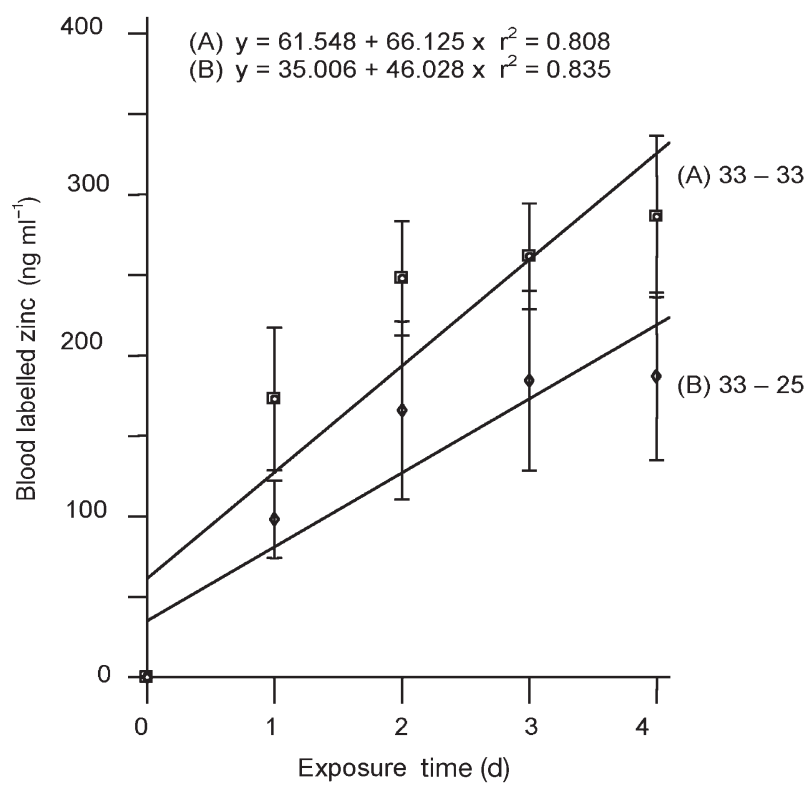

Fig. 6. Necora puber. Uptake of labelled zinc into the blood. Crabs were exposed for $4 \mathrm{~d}$ to $50 \mathrm{\mu g} \mathrm{l}^{-1}$ labelled $\mathrm{Zn}$ at salinities of (A) 33 and (B) 22 (mean $\pm 1 \mathrm{SD}, \mathrm{n}=8$ ) after $7 \mathrm{~d}$ preexposure to 33 


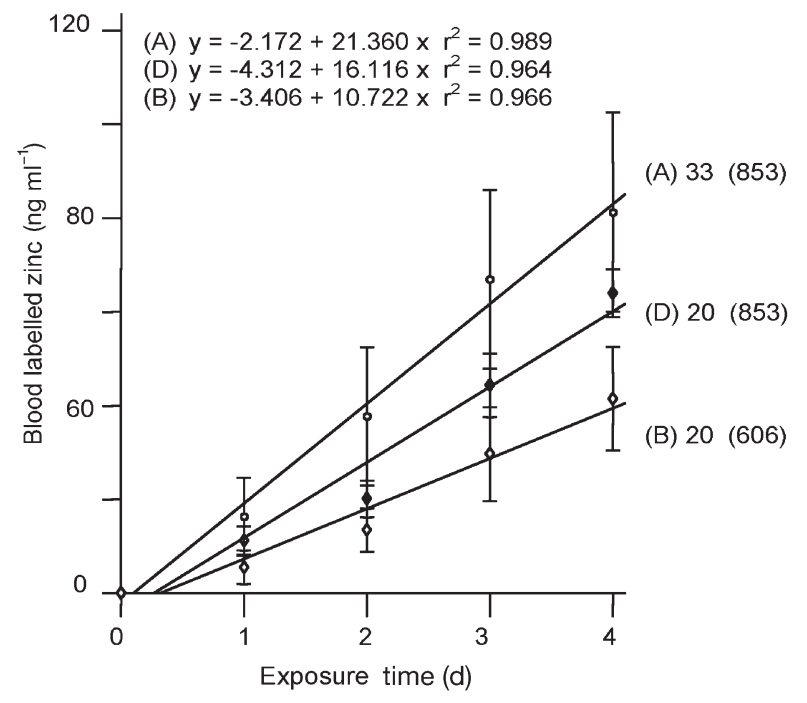

Fig. 7. Carcinus maenas. Effect of changing osmolality on the uptake of labelled zinc into the blood of acclimated crabs exposed for $4 \mathrm{~d}$ to $50 \mathrm{\mu g} \mathrm{l}^{-1}$ labelled $\mathrm{Zn}$ at salinities of (A) 33 (853 mOsm kg-1), (B) 20 (606 mOsm kg$~^{-1}$ ), and (D) 20 (adjusted to 853 mOsm kg${ }^{-1}$ ) (mean $\pm 1 \mathrm{SD}, \mathrm{n}=7$ ) after $7 \mathrm{~d}$ pre-exposure to the same conditions

uptake into the blood of crabs in Groups B and D (ANCOVA: $F S=0.90, \mathrm{df}=2,68, \mathrm{p}<0.05$ ).

Fig. 8 shows the same picture when the lower salinity is 15 as opposed to 20 . The decreases in salinity and osmolality from 33 to 15 (853 to $432 \mathrm{mOsm} \mathrm{kg}^{-1}$ ) are associated with a decrease in zinc uptake rate into the blood, a smaller decrease being observed when the salinity but not the osmolality is changed. Thus, the rates of labelled zinc uptake at a salinity of 15 of crabs in Group C and Group E (Fig. 8) were significantly lower (ANCOVA: A and C Fs $=15.2, \mathrm{df}=2,68, \mathrm{p}<0.01$; $\mathrm{A}$ and $\mathrm{E} F S=9.30, \mathrm{df}=2,68, \mathrm{p}<0.01$ ) than the rate of crabs in Group A. There was also a significant difference between zinc uptake rates into the blood between crabs in Groups $\mathrm{C}$ and E (ANCOVA: $F s=35.2, \mathrm{df}=2,68, \mathrm{p}<0.01$ ).

Comparison of the regression coefficients of Group D (20 at $853 \mathrm{mOsm} \mathrm{kg}{ }^{-1}$ ) and $\mathrm{E}$ (15 at $853 \mathrm{mOsm} \mathrm{kg}{ }^{-1}$ ) indicated that there was no difference between the rates of labelled zinc uptake into the blood of these crabs (ANCOVA: $F s=0.00, \mathrm{df}=2,68, \mathrm{p}=0.97$ ).

Thus, a change in the salinity of the medium from 33 to either 20 or 15 affected the uptake rate of zinc into the blood of Carcinus maenas, independently of any change in osmolality. Higher osmolality at salinities of either 20 or 15 increased the rate of zinc uptake.

\section{Eriocheir sinensis}

Similar experiments were carried out for Eriocheir sinensis but over a lower range of salinities. Fig. 9

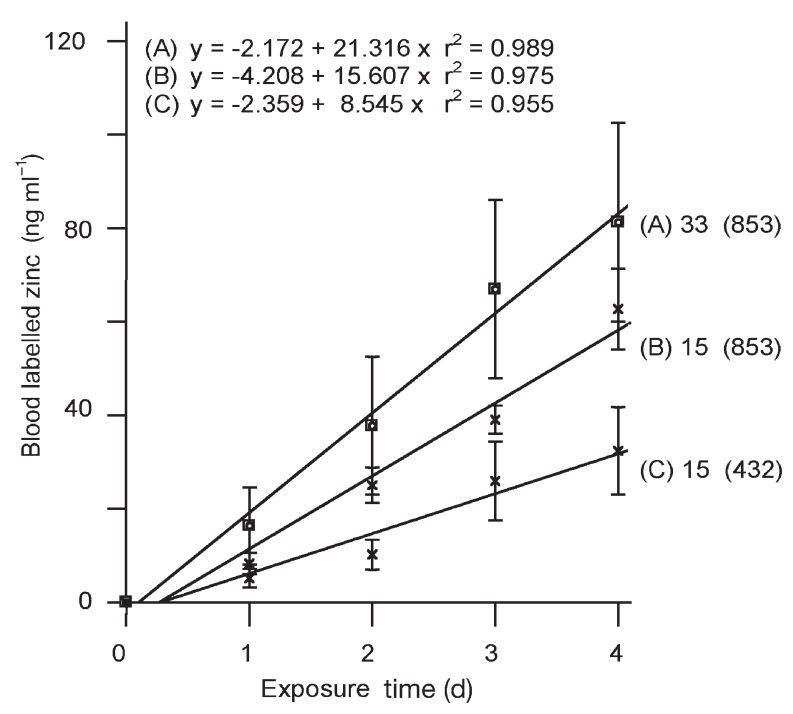

Fig. 8. Carcinus maenas. Effect of changing osmolality on the uptake of labelled zinc into the blood of acclimated crabs exposed for $4 \mathrm{~d}$ to $50 \mathrm{\mu g} \mathrm{l}^{-1}$ labelled $\mathrm{Zn}$ at salinities of (A) 33 (853 mOsm kg-1), (C) 15 (432 $\mathrm{mOsm} \mathrm{kg}^{-1}$ ), and (E) 15 (adjusted to 853 mOsm kg${ }^{-1}$ ) (mean $\pm 1 \mathrm{SD}, \mathrm{n}=7$ ) after $7 \mathrm{~d}$ pre-exposure to the same conditions

shows the uptake rates of labelled zinc into the blood of crabs exposed to zinc at salinities of 15 and 10 at normal osmolalities (432 and $261 \mathrm{mOsm} \mathrm{kg}^{-1}$ ), and at a salinity of 10 with the higher osmolality (432 mOsm $\mathrm{kg}^{-1}$ ). Fig. 10 similarly shows uptake rates for crabs exposed at 15 and 5 salinities (432 and 137 mOsm $\mathrm{kg}^{-1}$ ), and at a salinity of 5 at an osmolality of $432 \mathrm{mOsm} \mathrm{kg}{ }^{-1}$.

The uptake rates of labelled zinc into the blood of Eriocheir sinensis at 15 (Group A), 10 (Group B) and 5 (Group C) at normal osmolalities (432, 261 and 137 mOsm $\mathrm{kg}^{-1}$ ) followed the trend of increased uptake with reduced salinity observed earlier (Fig. 4). Uptake rates in Groups A and B were not significantly different from each other (ANCOVA: $\mathrm{A}$ and $\mathrm{B} F S=$ $1.11, \mathrm{df}=2,48, \mathrm{p}=0.30$ ), but the uptake rate in Group $\mathrm{C}$ was significantly raised above both $(\mathrm{A}$ and $\mathrm{C} F \mathrm{~F}=$ 8.42, df $=2,48, \mathrm{p}<0.01 ; \mathrm{B}$ and $\mathrm{C} F S=5.98, \mathrm{df}=2,48$, $\mathrm{p}<0.05)$.

Figs. $9 \& 10$ also illustrate the effect of a change in salinity but not osmolality on the rate of zinc uptake into the blood of Eriocheir sinensis, from 15 to 10 (Fig. 9) and from 15 to 5 (Fig.10). In both cases the change in salinity, while osmolality has remained unchanged, has caused an increase in zinc uptake rate, not significantly so in the change to 10 (ANCOVA A and D Fs $=1.52, \mathrm{df}=$ $2,48, \mathrm{p}=0.22$ ) but significantly for 15 to 5 (A and $\mathrm{E} F S=$ $24.2, \mathrm{df}=2,48, \mathrm{p}<0.01$ ). There was also a significant difference in zinc uptake rate between crabs in Groups $\mathrm{D}\left(10,432 \mathrm{mOsm} \mathrm{kg}^{-1}\right)$ and $\mathrm{E}\left(5,432 \mathrm{mOsm} \mathrm{kg}^{-1}\right)$ (D and E $F S=5.88, \mathrm{df}=2,48, \mathrm{p}<0.05)$. 

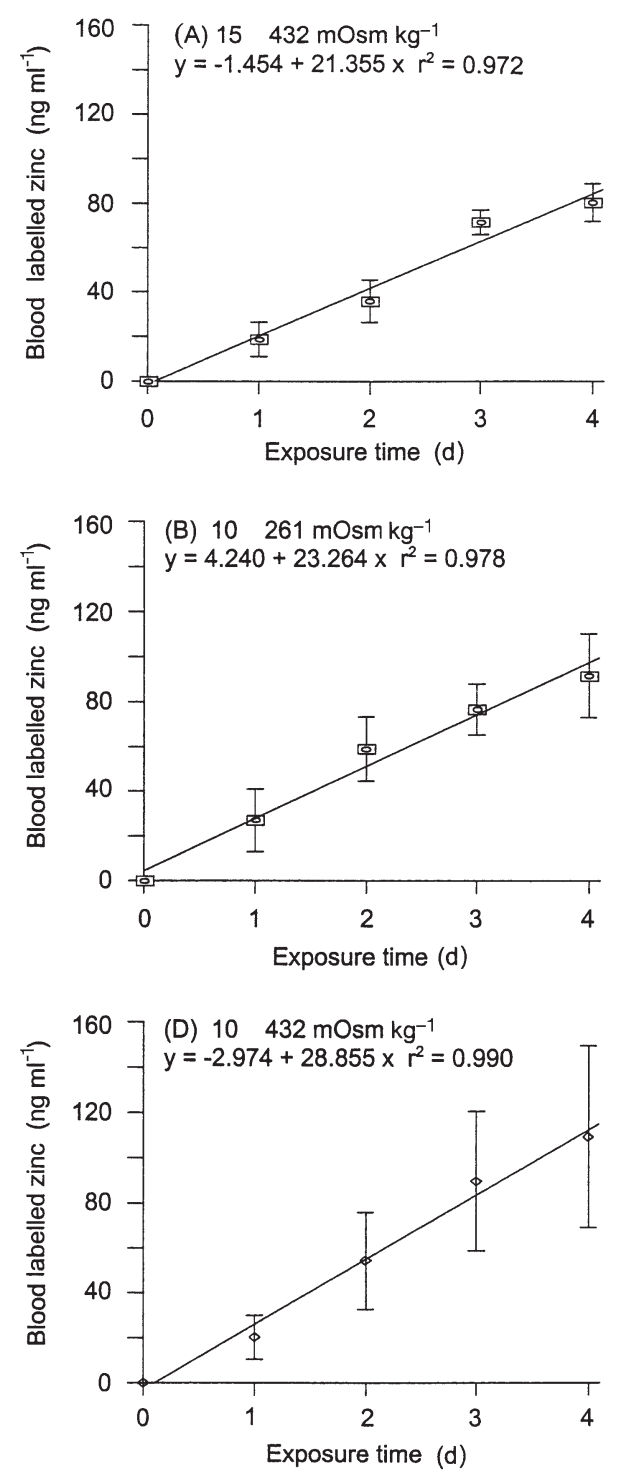

Fig. 9. Eriocheir sinensis. Effect of changing osmolality on the uptake of labelled zinc into the blood of acclimated crabs exposed for $4 \mathrm{~d}$ to $50 \mathrm{\mu g} \mathrm{l}^{-1}$ labelled $\mathrm{Zn}$ at salinities of (A) 15 (432 mOsm kg-1), (B) 10 (261 mOsm kg-1), and (D) 10 (adjusted to $432 \mathrm{mOsm} \mathrm{kg}{ }^{-1}$ ) (mean $\pm 1 \mathrm{SD}, \mathrm{n}=5$ ) after $7 \mathrm{~d}$ pre-exposure to the same conditions

Fig. 9 shows that there was no significant difference between the mean rates of labelled zinc uptake into the blood of Eriocheir sinensis in Group B at 10 (261 mOsm $\mathrm{kg}^{-1}$ ) and Group D at 10 (432 mOsm kg ${ }^{-1}$ ) (ANCOVA: $\left.F_{S}=1.98, \mathrm{df}=2,48, \mathrm{p}=0.17\right)$. Similarly, at a salinity of 5 the rates of labelled zinc uptake did not change when the osmolality of the medium was raised from 137 (Group C) to 432 (Group E) mOsm kg ${ }^{-1}$ (ANCOVA: $F S=0.17, \mathrm{df}=2,48, \mathrm{p}=0.68$ ) (Fig. 10). Therefore, raising the osmolality of the exposure medium had no effect on the uptake of labelled zinc into the blood of E. sinensis at salinities of both 10 and 5 .

\section{Necora puber}

Fig. 11 shows the effects of a reduction in salinity from 33 to 25 (with and without the expected change in osmolality from 853 to mOsm $\mathrm{kg}^{-1}$ ) on the uptake of labelled zinc into the blood of Necora puber.

The rates of labelled zinc uptake were significantly lower $(\mathrm{p}<0.05)$ at a salinity of 25 than at 33 , both when the osmolality changed (A and C Fs $=6.00, \mathrm{df}=2,68$, $\mathrm{p}<0.05)$ and when it remained at $853 \mathrm{mOsm} \mathrm{kg}^{-1}$ (A and B Fs $=4.67, \mathrm{df}=2,68, \mathrm{p}<0.01$ ). There was no


Fig. 10. Eriocheir sinensis. Effect of changing osmolality on the uptake of labelled zinc into the blood of acclimated crabs exposed for $4 \mathrm{~d}$ to $50 \mathrm{\mu g} \mathrm{l}^{-1}$ labelled $\mathrm{Zn}$ at salinities of (A) 15 $\left(432 \mathrm{mOsm} \mathrm{kg} \mathrm{kg}^{-1}\right.$ ), (C) 5 (137 mOsm kg${ }^{-1}$ ), and (E) 5 (adjusted to $432 \mathrm{mOsm} \mathrm{kg}^{-1}$ ) (mean $\pm 1 \mathrm{SD}, \mathrm{n}=5$ ) after $7 \mathrm{~d}$ pre-exposure to the same conditions 

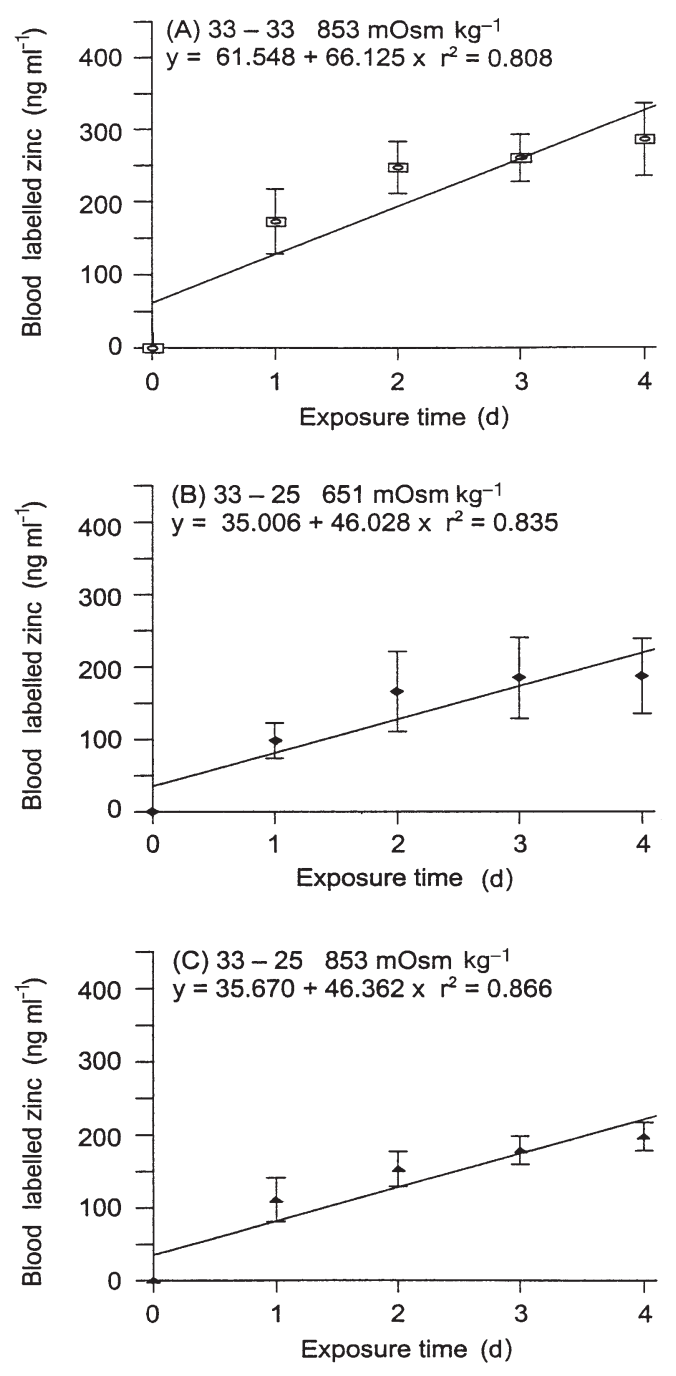

Fig. 11. Necora puber. Effect of changing osmolality on the uptake of labelled zinc into the blood of crabs exposed for $4 \mathrm{~d}$ to $50 \mathrm{\mu g} \mathrm{l}^{-1}$ labelled $\mathrm{Zn}$ at salinities of (A) $33\left(853 \mathrm{mOsm} \mathrm{kg}^{-1}\right)$, (B) $25\left(651 \mathrm{mOsm} \mathrm{kg}^{-1}\right)$, and (C) 25 (adjusted to $853 \mathrm{mOsm}$ $\mathrm{kg}^{-1}$ ) (Mean $\pm 1 \mathrm{SD}, \mathrm{n}=5$ ) after $7 \mathrm{~d}$ pre-exposure to 33 (853 $\mathrm{mOsm} \mathrm{kg}^{-1}$ )

significant difference $(F S=0.00, \mathrm{df}=2,68, \mathrm{p}=0.96)$ between the uptake rates of labelled zinc into the blood of Groups B $\left(25,651 \mathrm{mOsm} \mathrm{kg}{ }^{-1}\right)$ and C $(25,853 \mathrm{mOsm}$ $\mathrm{kg}^{-1}$ ), indicating that a change in osmolality of the exposure medium had no significant effect on the uptake rates of zinc into Necora puber at the salinity of 25.

\section{DISCUSSION}

The effects of salinity change on the rate of zinc uptake by the crabs varied interspecifically. In the case of Carcinus maenas, the zinc uptake rate decreased with salinity decrease, as found for C. maenas from the same site of origin by Chan et al. (1992). This decrease in zinc uptake rate occurred in both acclimated and non-acclimated crabs, although the decrease in uptake rate was not as great in the non-acclimated crabs as in those acclimated to the lower salinity for $7 \mathrm{~d}$. These results are consistent with $C$. maenas making a physiological response to reduced salinity that more than counteracts the expected physicochemical effects of increased free zinc ion availability at lower salinities. It also appears that acclimation to a lower salinity for $7 \mathrm{~d}$ has produced a greater (more complete?) physiological response than was seen in the non-acclimated crabs. Transfer of $C$. maenas from 20 to 33 salinity without reacclimation did not restore the zinc uptake rate of the crabs to the higher zinc uptake rate measured in crabs acclimated to 33, suggesting that the physiological change that occurred at 20 was still affecting the zinc uptake rate after transfer to the higher salinity.

A different pattern was observed in the case of the mitten crab Eriocheir sinensis. Zinc uptake rates were much lower than in the other 2 species (see Table 1), but increased with decrease in salinity in both acclimated and non-acclimated crabs. Such an increase would be expected from changes in free zinc ion availabilities resulting from the physicochemical effect of reduced salinity on dissolved zinc speciation. Consistent with these results is the interpretation that $E$. sinensis, in being adapted to life in freshwater, already has a very low AWP (causing a low zinc uptake rate) and makes little or no further change in AWP in response to salinity changes. Thus the zinc uptake rate responds to changes in free zinc ion concentrations resulting from the physicochemical effects of reduced salinity, increasing (from a low base) as salinity is decreased. This effect is the same as that seen in Palaemon elegans (Nugegoda \& Rainbow 1989a,b) with no change in AWP on the part of this decapod (Campbell \& Jones 1990).

It was Necora puber that, as our stenohaline marine model, was expected to show no physiological response to salinity reduction. Thus the zinc uptake rate was expected to increase with reduced salinity. In fact $N$. puber followed the Carcinus maenas and not the Palaemon elegans model, making a physiological re-

Table 1. Mean $( \pm 1 \mathrm{SD})$ uptake rates of zinc into the blood of 3 crabs exposed to $50 \mu \mathrm{g} \mathrm{l}^{-1}$ labelled $\mathrm{Zn}$ at a salinity of 33 at $10^{\circ} \mathrm{C}$

\begin{tabular}{|c|c|c|}
\hline Crab species & $\mathrm{N}$ & $\begin{array}{l}\text { Zinc uptake rate } \\
n g \mathrm{ml}^{-1} \mathrm{~d}^{-1}\end{array}$ \\
\hline Necora puber & 7 & $66.1 \pm 10.3$ \\
\hline Carcinus maenas & 7 & $21.3 \pm 5.50$ \\
\hline Eriocheir sinensis & 8 & $5.19 \pm 1.66$ \\
\hline
\end{tabular}


sponse and showing a decrease in zinc uptake rate between salinities of 33 and 25 .

Can the physiological effect identified above be reconciled with the results now available for changes in AWP in these crabs with change in salinity (Rainbow \& Black 2001)? Indeed they can. Rainbow \& Black (2001) showed that Carcinus maenas from the Firth of Clyde is able to alter AWP progressively in response to decreases in salinity. Eriocheir sinensis did not significantly change its apparent water permeability in response to a lowering of salinity from 33 to 5, and its permeability is already very low (Rainbow \& Black 2001). Furthermore Necora puber can reduce its high apparent water permeability (AWP) after $1 \mathrm{~d}$ acclimation from 33 to the lower salinity of 25 (Rainbow \& Black 2001), presumably in reflection of its ability to survive at least some emersion (and subsequent potential variation in parameters including salinity in tidepools affected by evaporation or rainfall) at the bottom of a shore.

What light do the experiments changing salinity and osmolality independently bring to bear on the above interpretation? In the case of Carcinus maenas, zinc uptake rates in crabs in media at 15 (or 20) salinity with osmolalities equivalent to 15 (or 20) and 33 salinities were still reduced from those in 33 salinity. This reduction was not, however, as great in the medium of lower salinity but higher osmolality. Thus there was still a physiological response made, counteracting the physicochemical enhancement of free zinc ion availability, a result unexpected if AWP change were the sole physiological response made and if AWP responds solely to changes in the total osmotic pressure of the medium. Thus either other physiological responses to low salinity are present in C. maenas offsetting physicochemical effects on zinc speciation (as in Orchestia gammarellus - Rainbow \& Kwan 1995), and/or the change in AWP in C. maenas is not simply a response to total osmolality, but (in part at least) to a change in the concentration of an inorganic species such as chloride. The situation for Necora puber was not dissimilar. Zinc uptake rates did not differ in media of 25 salinity with osmolalities equivalent to salinities of 25 and 33. Thus, N. puber still makes a physiological response at a salinity of 25 irrespective of the osmolality, offsetting speciation effects, as in the case of C. maenas.

In the case of Eriocheir sinensis, the change of osmolality (but not salinity) in media of either 5 or 10 salinity to that of a 15 salinity medium caused no significant change of zinc uptake rate. This is consistent with the crabs making no physiological response to salinity or osmolality change as interpreted above.

Subsequently to these experiments Roast et al. (2002) investigated zinc uptake by Eriocheir sinensis at salinities either side of the isosmotic point (equivalent to a salinity of 32.7 in this case), keeping the free zinc ion concentration constant. The zinc uptake rate did not differ significantly between crabs exposed at salinities of 22.7, 32.7 and 42.7 , in accordance with the interpretation here that the zinc uptake rate of $E$. sinensis is predominantly controlled by the free zinc ion concentration with little physiological intercession.

The interaction of physiology and physicochemistry in controlling trace metal uptake from solution clearly varies interspecifically. It is tempting to speculate that the ability to make physiological responses to changes in environmental parameters may not be common across marine invertebrates, but may be a feature of those invertebrates that by the very possession of such physiological versatility are able to occupy littoral and estuarine habitats, and be labelled with the possibly derogatory epithet of 'common'.

Acknowledgements. This research was supported by a studentship from the BBSRC. We would like to thank Brian Smith for his considerable technical help with experiments.

\section{LITERATURE CITED}

Bolt SRL (1983) Haemolymph concentration and apparent permeability in varying salinity conditions of Gammarus duebeni, Chaetogammarus marinus and Gammarus locusta. J Exp Biol 107:129-140

Bruland KW (1983) Trace elements in seawater. In: Riley JP, Chester R (eds) Chemical oceanography, Vol 8. Academic Press, London, p 157-220

Campbell PGC (1995) Interaction between trace metals and aquatic organisms: a critique of the free-ion activity model. In: Tessier A, Turner DR (eds) Metal speciation and aquatic systems. Wiley, New York, p 45-102

Campbell PJ, Jones MB (1990) Water permeability of Palaemon longirostris and other euryhaline caridean prawns. J Exp Biol 150:145-158

Chan HM, Bjerregaard P, Rainbow PS, Depledge MH (1992) Uptake of zinc and cadmium by two populations of shore crabs Carcinus maenas at different salinities. Mar Ecol Prog Ser 86:91-97

Clark PF, Rainbow PS, Robbins RS, Smith BD, Yeomans WE, Thomas M, Dobson G (1998) The alien Chinese mitten crab, Eriocheir sinensis (Crustacea: Decapoda: Brachyura) in the Thames catchment. J Mar Biol Assoc UK 78: 1215-1221

Frausto da Silva JR, Williams RJP (1991) The biological chemistry of the elements. Clarendon Press, Oxford

Henry RP, Cameron JN (1982) Acid base balance in Callinectes sapidus during acclimation from high to low salinity. J Exp Biol 101:255-264

Ingle RW (1980) British crabs. Oxford University Press, Oxford

Mantel LH, Farmer LL (1983) Osmotic and ionic regulation. In: Bliss DE, Mantel LH (eds) The biology of crustacea. Vol 5 Internal anatomy and physiological regulation. Academic Press, New York, p 53-161

Mantoura RFC, Dickson A, Riley JP (1978) The complexation of metals with humic materials in natural waters. Estuar Coast Mar Sci 6:387-408

Martin DJ, Rainbow PS (1998a) The kinetics of zinc and cad- 
mium in the haemolymph of the shore crab Carcinus maenas (L.). Aquat Toxicol 40:203-231

Martin DJ, Rainbow PS (1998b) Haemocyanin and the binding of cadmium and zinc in the haemolymph of the shore crab Carcinus maenas (L.). Sci Total Environ 214:133-152

Nieboer E, Richardson DHS (1980) The replacement of the nondescript term 'heavy metals' by a biologically and chemically significant classification of metal ions. Environ Pollut Bull 1:3-26

Nugegoda D, Rainbow PS (1988) Effect of a chelating agent (EDTA) on zinc uptake and regulation by Palaemon elegans (Crustacea: Decapoda). J Mar Biol Assoc UK 68: $25-40$

Nugegoda D, Rainbow PS (1989a) Effects of salinity changes on zinc uptake and regulation by the decapod crustaceans Palaemon elegans and Palaemonetes varians. Mar Ecol Prog Ser 51:57-75

Nugegoda D, Rainbow PS (1989b) Salinity, osmolality, and zinc uptake in Palaemon elegans (Crustacea: Decapoda). Mar Ecol Prog Ser 55:149-157

O'Brien P, Rainbow PS, Nugegoda D (1990) The effect of the chelating agent EDTA on the rate of uptake of zinc by Palaemon elegans (Crustacea: Decapoda). Mar Environ Res 30:155-159

Rainbow PS (1995) Physiology, physicochemistry and metal uptake - a crustacean perspective. Mar Pollut Bull 31: 55-59

Rainbow PS (1997) Ecophysiology of trace metal uptake in crustaceans. Estuar Coast Shelf Sci 44:169-175

Rainbow PS (1998) Phylogeny of trace metal accumulation in crustaceans. In: Langston WJ, Bebianno M (eds) Metal metabolism in aquatic environments. Chapman \& Hall, London, p 285-319

Rainbow PS, Black WH (2001) Effects of changes in salinity on the apparent water permeability of three crab species: Carcinus maenas, Eriocheir sinensis and Necora puber. J Exp Mar Biol Ecol 264:1-13

Rainbow PS, Kwan MKH (1995) Physiological responses and the uptake of cadmium and zinc by the amphipod crustacean Orchestia gammarellus. Mar Ecol Prog Ser 127: 87-102

Rainbow PS, Amiard-Triquet C, Amiard JC, Smith BD, Best SL, Nassiri Y, Langston WJ (1999) Trace metal uptake rates in crustaceans (amphipods and crabs) from coastal sites in NW Europe differentially enriched with trace metals. Mar Ecol Prog Ser 183:189-203

Rainbow PS, Amiard-Triquet C, Amiard JC, Smith BD, Langston WJ (2000) Observations on the interaction of zinc and cadmium uptake rates in crustaceans (amphipods and

Editorial responsibility: Otto Kinne (Editor), Oldendorf/Luhe, Germany crabs) from coastal sites in UK and France differentially enriched with trace metals. Aquat Toxicol 50:189-204

Rainbow PS, Malik I, O'Brien P (1993) Physicochemical and physiological effects on the uptake of dissolved zinc and cadmium by the amphipod crustacean Orchestia gammarellus. Aquat Toxicol 25:15-30

Rasmussen AD, Andersen O (1996) Apparent water permeability as a physiological parameter in crustaceans. J Exp Biol 199:2555-2564

Rasmussen AD, Bjerregaard P (1995) The effect of salinity and calcium concentration on the apparent water permeability of Cherax destructor, Astacus astacus and Carcinus maenas (Decapoda, Crustacea). Comp Biochem Physiol 111A:171-175

Rees DG (1987) Foundations of statistics. Chapman \& Hall, London

Roast SD, Rainbow PS, Smith BD, Nimmo M, Jones MB (2002) Trace metal uptake by the Chinese mitten crab Eriocheir sinensis: the role of osmoregulation. Mar Environ Res 53: 453-464

Rudy PP (1967) Water permeability in selected Decapod Crustacea. Comp Biochem Physiol 22:581-589

Simkiss K (1996) Ecotoxicants at the cell membrane barrier. In: Newman $\mathrm{MC}$, Jagoe $\mathrm{CH}$ (eds) Ecotoxicology. A hierarchical treatment. Lewis Publishers, Boca Raton, p 59-83

Simkiss K, Taylor MG (1989) Metal fluxes across the membranes of aquatic organisms. Aquat Sci 1:173-188

Simkiss K, Taylor MG (1995) Transport of metals across membranes. In: Tessier A, Turner DR (eds) Metal speciation and bioavailability in aquatic systems. John Wiley \& Sons, Chichester, $\mathrm{p}$ 1-44

Smith RI (1970) The apparent water-permeability of Carcinus maenas (Crustacea, Brachyura, Portunidae) as a function of salinity. Biol Bull (Woods Hole) 139:351-362

Sokal RR, Rolf FJ (1969) Biometry. WH Freeman \& Co, San Francisco

Tessier A, Buffle J, Campbell PGC (1994) Uptake of trace metals by aquatic organisms. In: Buttle J, De Vitre RR (eds) Chemical and biological regulation of aquatic systems. Lewis Publishers, Boca Raton, p 197-230

Turner DR (1995) Problems in metal speciation modelling. In: Tessier A, Turner DR (eds) Metal speciation and bioavailability in aquatic systems. John Wiley \& Sons, Chichester p 149-203

Williams RJP (1981) Physico-chemical aspects of inorganic transfer through membranes. Phil Trans R Soc Lond B 294: $57-74$

Williams RJP, Frausto da Silva JR (1996) The natural selection of the chemical elements. Clarendon Press, Oxford

Submitted: June 25, 2002; Accepted: August 7, 2002

Proofs received from author(s): November 11, 2002 